\title{
DETERMINING WIND ENERGY POTENTIAL AREAS IN AZERBAIJAN BY USING GIS MULTI-CRITERIA DECISION ANALYSIS METHOD
}

\author{
Imamverdiyev N.S. \\ Institute of Geography, Azerbaijan National Academy of Sciences \\ 115, H. Javid Ave., Baku, AZ1070, Azerbaijan: imamverdiyev.nicat@gmail.com
}

Keywords: renewable energy sources, wind energy, environment, potential areas, cost of electricity
Summary. The paper aims to identify potential wind energy fields of Azerbaijan using a GISbased spatial multi-criteria analysis method. Also it is possible to prevent material and time loss by calculating the amount of electricity generation through this method. Accurate determination of the areas where wind turbines will be installed is an important criterion affecting the energy production amount of electrical stations. Based on the principles of location selection of wind turbines important conditions such as infrastructure, the impact of turbines on the surrounding areas, proximity to residential areas, the wind regime of the potential regions were assessed. Besides factors such as investment cost, operating cost, power factor and operating life which determine the cost of energy production in wind turbines were also analyzed. The Republic's technical wind energy potential has been estimated around the amount of 3.000 MW. In terms of location selection principles for wind power plants meteorological indicators of wind potential areas were analyzed by the GIS multi-criteria decision analysis method and as a result the acreage of the most technically suitable areas was determined as $1143 \mathrm{~km}^{2}$. Depending on the wind speed and power density of these designated areas the possible electricity generation amount was calculated as 4.2 billion $\mathrm{kWh}$ by modeling through the open-source System Advisor Model (SAM) application. This volume is equivalent to $17 \%$ of the country's current electricity demand. Moreover, the electricity generation value of wind farms will be installed in these areas equals an average of $\$ 0.037$ per $\mathrm{kWh}$, which promotes the widespread use of wind turbines to prevent environmental pollution.

(C) 2020 Earth Science Division, Azerbaijan National Academy of Sciences. All rights reserved.

\section{Introduction}

Wind energy sources which are a clean and inexhaustible source will be the main source in the electricity generation sector of the future for a long time. Global warming due to the increase in the number of harmful gases $\left(\mathrm{CO}_{2}, \mathrm{CO}\right.$, and $\left.\mathrm{NO}_{\mathrm{x}}\right)$ in the atmosphere and the greenhouse effect are considered as the biggest environmental problem in the world. The most appropriate method to reduce this problem is to give priority to renewable energy sources such as wind energy because the total amount of carbon emissions released into the atmosphere has increased to high rates. However, the World Meteorological Organization (WMO) has reported that globally averaged concentrations of carbon dioxide $\left(\mathrm{CO}_{2}\right)$ reached 407.8 parts per million in 2018, up from 405.5 parts per million (ppm) in 2017 (The state of greenhouse..., 2019).

Greenhouse gas emissions in Azerbaijan amounted to 29.8 million tons of $\mathrm{CO}_{2}$ equivalent (Environment in Azerbaijan..., 2019). As a result of this, the volume of carbon dioxide in the gas composition of the atmosphere has increased above normal and caused some differences in the reflection of the sun's rays. In particular this leads to global climate change by creating a greenhouse effect (Makhmudov, 2006). Although these indicators are the main factors, on the contrary, the effects of natural factors on climate change have also been suggested. The increase in gases that create heat effect does not affect heating in the atmosphere (Kapitsa, 2003). The researcher has claimed that the increase in the temperature ratio led to a further increase in the volume of such gases. Based on the analysis of both scientific claims about the rise of global temperatures it is possible to argue that both anthropogenic and natural factors influence climate change. Besides, these effects occurred simultaneously and mutually with each other causing the annual average temperature to rise to about $0.8^{\circ} \mathrm{C}$ (Porter et al., 2019).

A.S.Ayyubov and G.A.Hajiyev (1984) have studied climate resources and factors affecting the 
climate of Azerbaijan in detail. The meteorological data of Azerbaijan and the wind speed data calculated by the researchers have been compared. As a result, it was concluded that climate change has an impact on Azerbaijan's wind regime. Based on the analysis of the data between 1970 and 2015 in contrast to the current temperature increase in the country the windy day intensity has shortened and the annual average wind speed has estimated to decrease among 0.5-0.8 m/s (Observational materials..., 1990-2015). These analyses also include A.A.Madatzadeh's (1973) research on the weather types of the Absheron peninsula, the direction of the prevailing winds and the wind regime.

As a solution to the climate change problems mentioned above, clean energy technologies need to be developed rapidly. For this the potential of renewable energy sources should be determined and their methods of use should be researched. Of these N.A.Yusifbayli et al. (2018) have developed a model that determines the dependence of vertical axis turbines from the power density of wind in electricity production. Also SH.C.Shahbazov, I.M.Yusubov (2018) determined that the main factor determining efficiency in electricity generation depends on rotor diameter. Y.R.Abdullayev et al. (2018) investigated ways to improve the design and efficiency of vertical axis wind turbines.

There are the following examples of the application of a multi-criteria decision-making method (MCDM) in the study of the most suitable sites for the construction of wind farms. Thus, J.P.Huang et al. (1995) tried to determine the best method by using various MCDM such as ELECTRE, AHP, and TOPSIS to estimate the optimum locations of renewable energy stations. E.Georgopoulou et al. (1997) advantages and disadvantages of using renewable energy in Greek islands have investigated using the Electre III method. Also, M.Beccali et al. (1998) have used a multi-criteria decision analysis system to evaluate various energy alternatives in Italy. In addition H.R.Quijano et al. (2012) presented a tool called MODERGIS to simulate current renewable energy planning in the future according to various sustainability criteria. With this method the research area is first classified according to the wind energy potential and then the possible locations for the construction of the wind power plants are determined. For example, considering the environmental constraints to identify potential locations for wind farms, the suitability indexing and economic feasibility studies of wind fields were carried out using multi-criteria analysis in the ArcGIS environment (Al-Yahyai et al., 2012). GIS-based multi-criteria decision analysis method has been used to determine the most suitable installation location by taking into consideration the research theories of wind turbines. However there are many criteria that determine the choice of location for wind farms. The most important of these criteria is to make a detailed analysis of spatial data collected in Geographic Information Systems to determine suitable installation locations for wind turbines. Also the open-source System Advisor Model (SAM) application was used in addition to the appropriate formulas to identify wind potential areas.

\section{Materials and methods}

The main purpose of the article is to identify the most suitable locations for the installation of wind farms in the wind potential regions of the country. For this purpose wind meteorological data (19902015) literature sources were examined, appropriate programs and formulas were used. In order the wind turbines to work efficiently wind speed, the intensity of windy days, and high wind power, as well as conditions of relief and infrastructure must be at a certain level. Based on these requirements the wind regime of Azerbaijan was systematically analysed and grouped according to wind speed indicators. In terms of the environmental impacts of wind farms it is impossible to install wind turbines in all potential areas. For this purpose these exceptional areas require to be determined to calculate the wind power generation capacity of the country. A multi-criteria decision analysis method was created in a GIS environment using land use, environmental protection and metrology maps of the country to determine the technical potential of wind energy areas and the volume of electricity generation.

In this study the GIS-based multi-decision analysis method has been used in the selection of locations for wind power plants. At the same time mathematical-statistical, systematic analysis and modelling methods were used. Three different data types were used in the study to identify potential energy regions. These data types are the following:

Land use of the regions, relief of the areas, etc;

Meteorological condition of the regions;

Environmental impacts of the power plant.

By analyzing these 3 different databases, the GIS environment maps showing the areas suitable for the construction of wind power plants were created. During the study satellite images and online maps (Basemap) in the Digital Terrain Model database were used to obtain the necessary information. Firstly the data obtained from the Digital Terrain Analysis database were transferred to the WGS84 $39 \mathrm{~N}$ coordinate system, and the slope and direction of the area examined with the vector of the maps were determined. Grid Analysis was used to determine the meteorological conditions of potential are- 
as, and the identified intermediate values were processed in raster format where distance analysis was performed. However in determining wind potential areas criteria such as access roads, residential areas, power lines and protected areas were analyzed in the GIS environment by the cartographic method. For each category of data the reclassification analysis was done using the ranges shown in Tables 1 and 2, and the maps were compiled graded as best appropriate and least suitable. The basic data of the regions are reviewed in the GIS environment and systematized according to the purpose and then the analysis of the location of the wind turbines is continued with the proposed MCDM methodology. Finally the figures obtained by using the model weighted overlay method are re-evaluated.

\section{Analysis and discussion}

The Caspian Sea and orographic structure of the Great Caucasus Mountains perform a pivotal role in the formation of the wind regime in the Republic of Azerbaijan. So that, the Greater Caucasus mountains not only obstruct the northern winds (Khazri), also cause the winds to the east direction. At the same time the south-eastern part of the country is mainly under the influence of the southern winds (Gilavar) in the summer months (Madatzadeh, 1973;
Ayyubov, 1997). However there are offshore Breeze winds that cause to form air masses on various sides of the peninsula under the influence of the Caspian Sea. As a result of this circulation medium and highspeed winds occur on the Absheron peninsula. In the Caspian Sea and in the coastal areas of the Absheron peninsula winds of more than 25 meters per second are formed with an average of 25-30 days a year. Therefore it is necessary to use high-quality wind turbines at the stations planned to be installed in these regions. These areas include Pirallahi, Chilov, Puta, Sumgait, Shubani, and Bina stations with average annual wind speeds exceeding $5.5 \mathrm{~m} / \mathrm{s}$ (National Atlas: Azerbaijan Republic, 2014).

Another high potential region of Azerbaijan is the southeastern part of the Nakhchivan Autonomous Republic. The geographical location of Nakhchivan has led to the formation of strong winds in the region as a result of the combination of two distinct air currents. These winds are mostly cold arctic winds and warm southern winds of tropical origin (Ayyubov, Hajiyev, 1984).

The analysis of the average annual wind flow trends of both regions shows that $85 \%$ of the north winds dominate the Absheron peninsula and $90 \%$ of the southeast winds dominate the Nakhchivan Autonomous Republic (Fig.1).
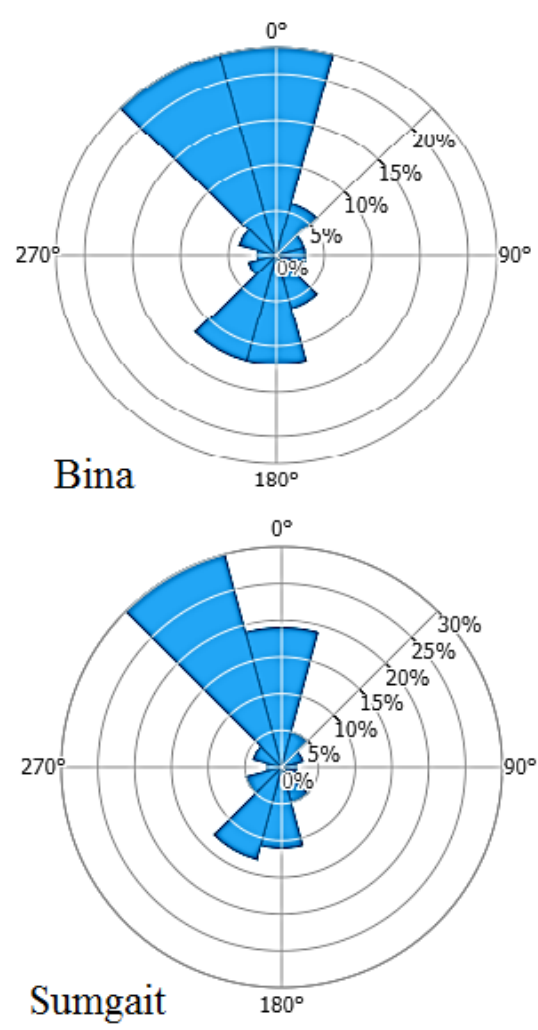

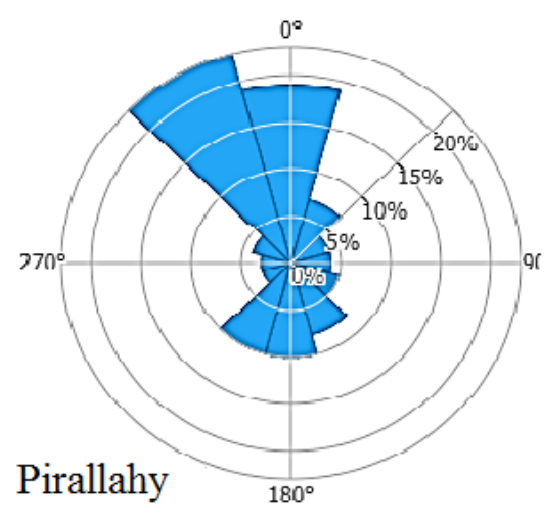

$0^{\circ}$

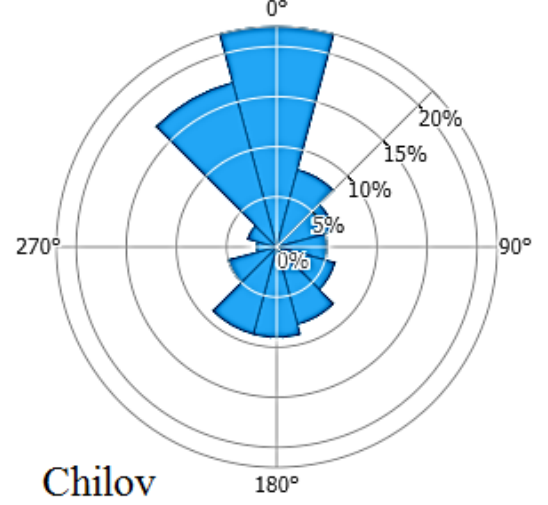

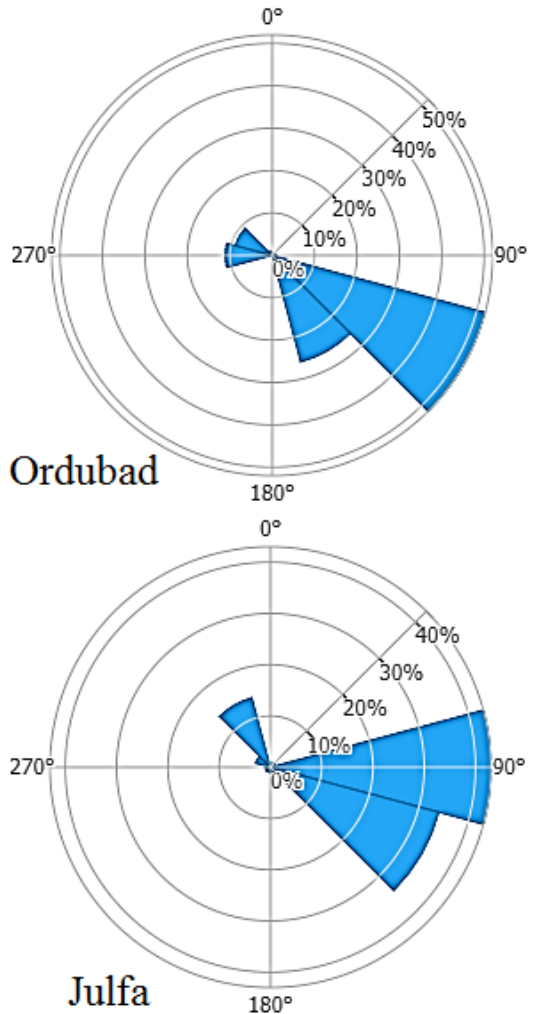

Fig. 1. Wind rose of Absheron peninsula and Nakhchivan AR (Shikhlinsky, 1978) 
The annual average wind speed is around 3.5 $\mathrm{m} / \mathrm{s}$ in Sahukh and Goranboy regions which are in the third place according to the wind speed distribution of Azerbaijan (Fig. 2) (National Atlas: Azerbaijan Republic, 2014). Due to the low wind speeds in these areas the power generation capacity of wind farms will be around $100-250 \mathrm{Wh} / \mathrm{m}^{2}$. The total wind energy potential area of this region is estimated to be $1380 \mathrm{~km}^{2}$. The average wind energy density is $417 \mathrm{~W} / \mathrm{m}^{2}$ at a relative height of 100 meters (Global wind atlas, 2019). As it seems the wind energy density is below average in these regions for the installation of wind power plants. This leads to a decrease in the capacity factor of wind turbines during operation. In addition as the wind intensity covers 110125 days of the year, the operation of power plants becomes economically inefficient in these regions (Ayyubov, Hajiyev, 1984). Note that for the most efficient operation of wind stations the wind density should be an average of $8 \mathrm{~m} / \mathrm{s}$. This rate is equal to the energy production of $80 \mathrm{Wh}$ per $\mathrm{m}^{2}$ area.

The share of wind energy in Azerbaijan's total electric production was $0.32 \%$ (82.7 million $\mathrm{kWh}$ ) in 2018. Besides, the electricity generation rate from renewable energy sources reached $8.1 \%$ (The energy of Azerbaijan..., 2019). The Azerbaijani government has invested 164.3 million manats for the con- struction of five wind farms in 2005-2015. Wind power plants started to operate from 2009 and produced 130 million $\mathrm{kWh}$ of electricity until 2019 in total $(2014,2015,2016$ energy efficiency report, 2017; 2015-2018 strategical plan, 2015). According to the country's wind energy tariff revenue from wind power sales has been only 7.15 million AZN.

Azerbaijan's total wind power potential has estimated to be around 3000 MW (Reports on the works in the field of energy, 2017-2019). Currently only $2.08 \%(62.4 \mathrm{MW})$ of this potential is using as a power source. Whereas it is possible to generate 6.3 billion $\mathrm{kWh}$ of electricity by fully utilizing the existing potential (Average capacity factor $24 \%$ ). The data of the country's wind regime demonstrators, the Environment Atlas and the Global Wind Atlas were analyzed to identify possible installation areas of wind stations across the country. For the wind turbines to start operating the polygons have drawn in the GIS system of the areas with a minimum wind speed of over $3.5 \mathrm{~m} / \mathrm{s}$, and the areas of the general potential were collected. Including exceptional areas the total area of these regions has been calculated as $5.621 \mathrm{~km}^{2}$ (Fig. 3). These areas include approximately $3900 \mathrm{~km}^{2}$ of the Absheron Peninsula, 1200 $\mathrm{km}^{2}$ of the Caspian Sea, $521 \mathrm{~km}^{2}$ of coastal areas of Aras in the areas of Julfa and Ordubad.

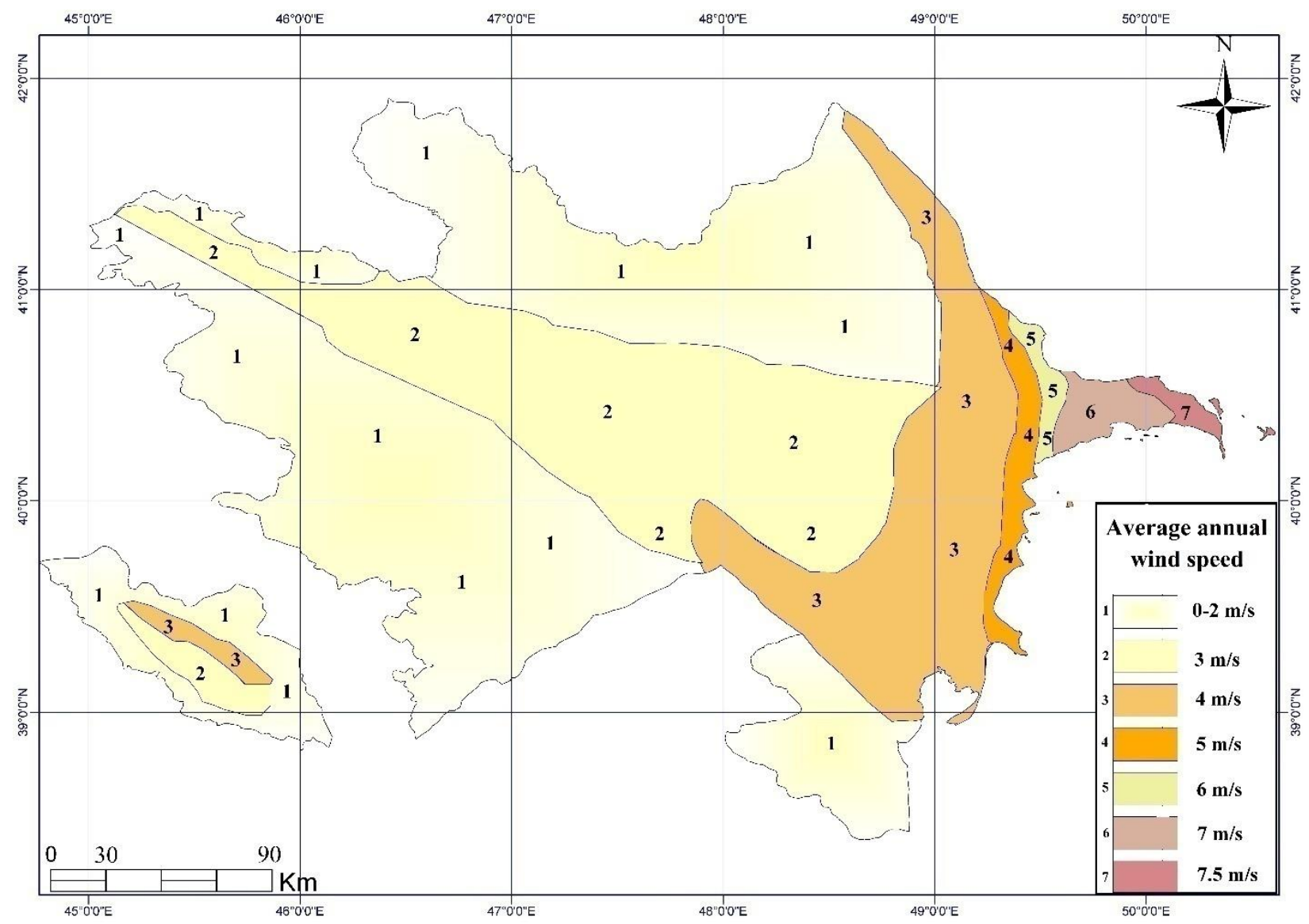

Fig. 2. Wind map of the Republic of Azerbaijan (10 metr altitude) (Observational materials..., 1990-2015) 


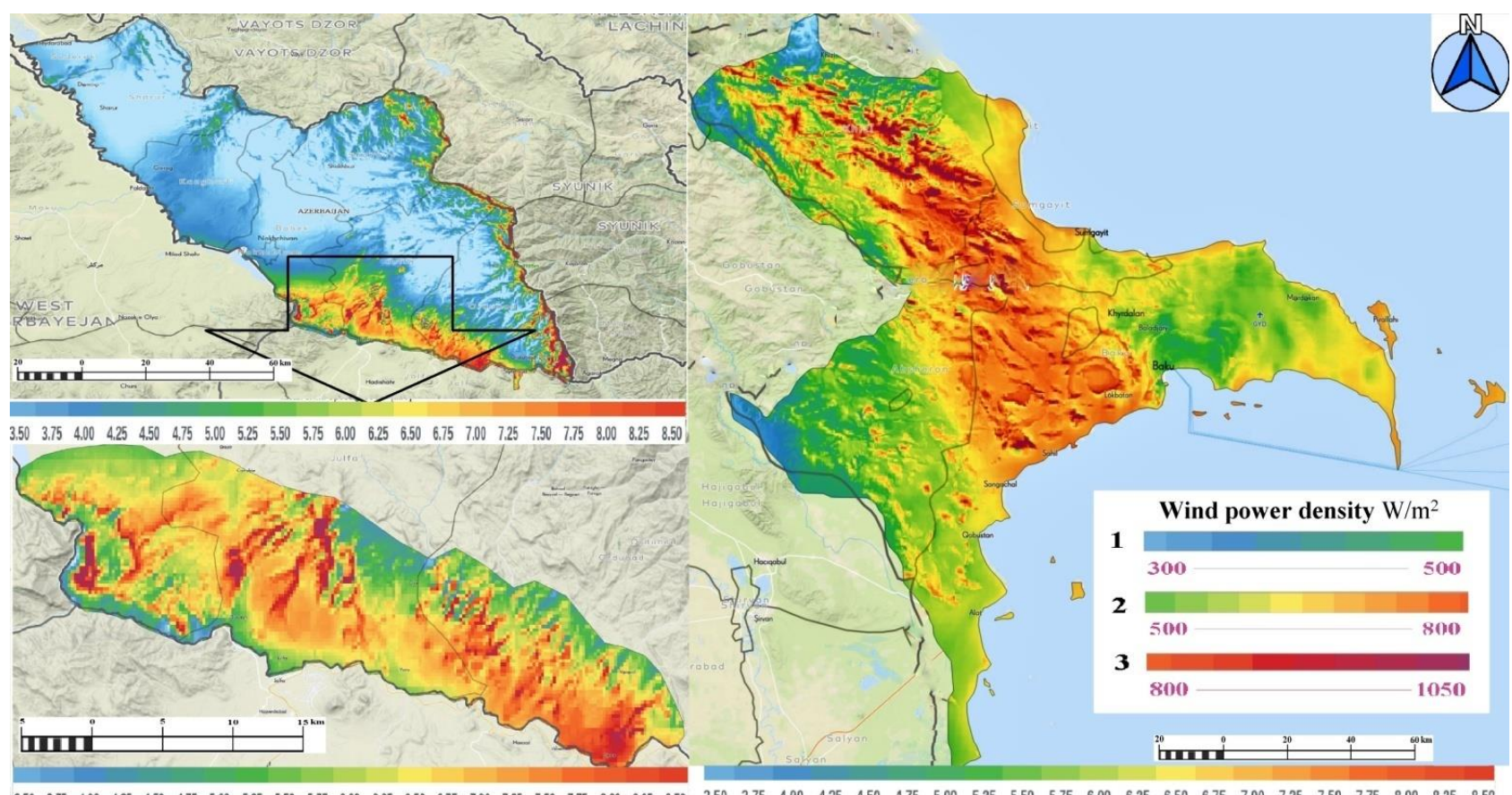

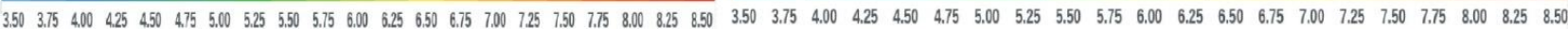

Fig. 3. Distribution of regions with wind energy potential in Azerbaijan by the density of wind power (50 m altitude), (Global wind atlas, 2019)

The potential wind areas in the Caspian Sea include the offshore coastal areas of the Absheron Peninsula and the Khizi district. The average wind energy density of the selected $5100 \mathrm{~km}^{2}$ potential areas has determined as 570 Watt per $\mathrm{m}^{2}$ based on the data provided by Global wind atlas. However it is impossible to build wind power plants in all areas with wind potential in terms of the environmental impact of turbines. Contrary to the overall potential of wind there are some indicators based on the selection of the most appropriate places for the establishment of wind stations. Economically it is more convenient to install wind turbines in open areas with an average annual wind speed of a minimum of $3.5 \mathrm{~m} / \mathrm{s}$ and more than 200 windy days. During the selection of areas for the establishment of wind power plants in terms of efficiency it is more suitable to install wind turbines on the shores of the sea, on open terrains and the mountain slopes. The identified areas should locate outside the settlement areas, close to the highways and electricity grid. Although wind power plants should be installed outside protected areas and settlements. Besides, the effects of wind stations on the landscape of the area, birds' migration routes and biologically sensitive areas should be considered.

A foundation for wind turbines has been established in the open-source System Advisor Model (SAM) for the establishment of power plants in high availability areas. Within the scope of the "SAM 18.11" program using the meteoro- logical data potential areas were investigated in accordance with the installation principles of wind turbines in the plinth created for power plants. The main purpose here is to identify geographical obstacles, legal restrictions, national parks and other private areas to identify technical potential areas (Chaouachi, 2017). For this aspect a geographic information database has been created in the GIS environment to identify excluded areas. The zones of wind potential were analysed in detail from the point of view of the principle of localization of wind turbines throughout the country. As a result the number of areas with high wind potential has been determined: 58 onshore and 5 in the offshore (Fig. 4). The total areas defined are $1143 \mathrm{~km}^{2}$ including $883 \mathrm{~km}^{2}$ on land and $260 \mathrm{~km}^{2}$ offshore. In addition the wind energy potential of the $\mathrm{Ab}$ sheron geographical region includes $72 \%$ of the country's total potential. As an example of these areas we can show the nearby fields of the settlements of Yeni Yashma, Gilezi, Turkoba, Turkan, Pirallahi, Qobu and Pirekeshkul (Fig. 4). Based on meteorological measurement data of these regions it was determined that the average annual wind speed is $8.7 \mathrm{~m} / \mathrm{s}$ and the wind energy density is $1046 \mathrm{~W} / \mathrm{m}^{2}$ (Observational materials ..., 19902015). These indicators are evaluated at medium and high-efficiency rates while choosing a place for the installation of wind turbines.

Since the technical characteristics of wind turbines are individual the best performance wind speed in modern wind turbines can be equal to or 
less than $8-10 \mathrm{~m} / \mathrm{s}$. Thus wind power plants can achieve electrical power generation at maximum power. Based on this, the areas in this ratio wind potential across the country are only available in the Absheron Peninsula, Julfa and Ordubad regions. In addition the days when wind speeds are between $8-11 \mathrm{~m} / \mathrm{s}$ establish $25 \%$ of the annual windy days in these regions (Madatzadeh, 1973).

The southern slopes of the Julfa and Ordubad regions of the Nakhchivan $\mathrm{AR}$ and the areas around the Aras River have high wind energy potential. As a result of our researches to select suitable places for the location of wind power plants 23 optimal polygons were identified in the region. As an example of these fields we can show fields near the settlements of Yayc1, Deste, Velever, Sabirkend, Dize, Gulustan and Nehram (Fig. 4). The possible total area for the installation of wind power plants is limited to $152 \mathrm{~km}^{2}$ in this region. The wind power density of the region varies between 720 and $1160 \mathrm{~W} / \mathrm{m}^{2}$ (Global Wind Atlas, 2019). The wind density of these areas was determined. It was analyzed that turbines up to $600 \mathrm{~kW}$ capacity have optimum indicators for installation.

The wind energy potential of the Caspian Sea constitutes $28 \%$ of the country's total wind energy capacity. The northeastern part of the Absheron peninsula and the seashore of Khizi district are the most suitable areas for the installation of wind turbines. Five regions have identified for the generation of electricity from wind energy in the Caspian Sea. The total area of these regions consti- tutes $260 \mathrm{~km}^{2}$ (Fig. 4). Wind turbines with a rotor diameter of approximately 100 meters should be installed for the efficient operation of wind farms in these areas because at this altitude the average annual wind speed is high and equals 8.9 meters per second (Observational materials ..., 19902015).

Using the open-source SAM program several simulation models have been created as an example to determine the possible annual production volume through wind farms in potentially windy regions. The main purpose here is to find the relative height of the wind turbines to determine the optimal energy production volume. Besides the energy production volume depends on the size of the areas required for the installation of wind turbines. Thus the area required for a 50-meter wind turbine is $1963 \mathrm{~m}^{2}$. However due to the turbulence effect of the winds, the space required for a turbine is theoretically about 3 times larger than the rotor blade diameter, so the turbines do not affect each other and the wind density regains maximum energy power until it reaches the turbine. In this case it is possible to calculate that the coverage area of a $2 \mathrm{MW}$ wind turbine is equal to $6070 \mathrm{~m}^{2}$ (Ragheb and Ragheb, 2011). However it is possible to install wind turbines with a capacity of 4.0 MW per $\mathrm{km}^{2}$ in general. Even if the wind speed exceeds the rated speed, the maximum amount of energy produced by the wind turbines cannot exceed the predicted theoretical power.

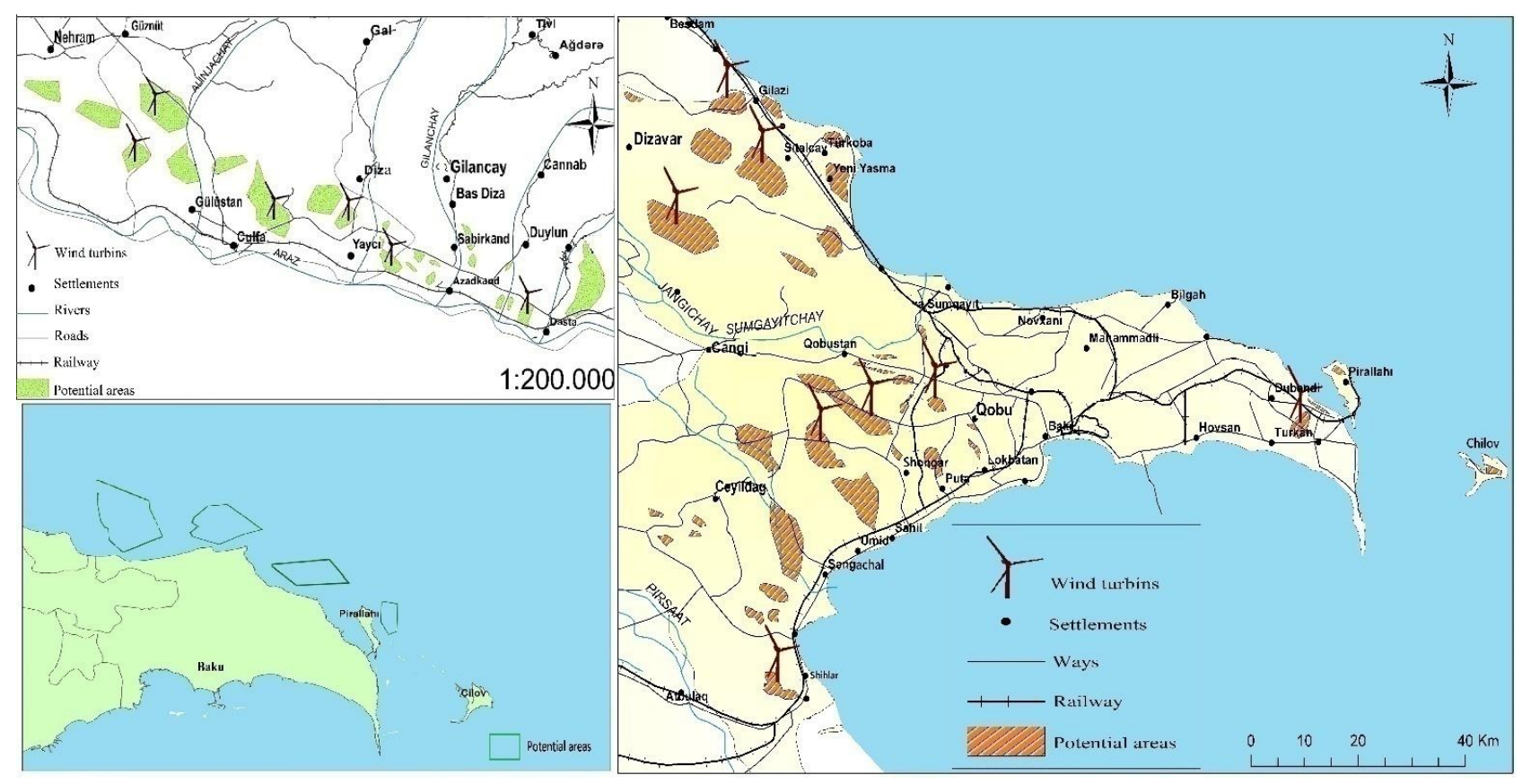

Fig. 4. Technically wind energy potential areas in Absheron region, Caspian Sea, Julfa and Ordubad 
Wind turbines start working when the wind speed is $3.5 \mathrm{~m} / \mathrm{s}$ and the operation stops automatically when the speed exceeds $25 \mathrm{~m} / \mathrm{s}$. However when the wind speed reaches $8 \mathrm{~m} / \mathrm{s}$ wind turbines generate electricity at maximum power and this power remains unchanged even if the wind speed rises to $25 \mathrm{~m} / \mathrm{s}$ (Fagiano, 2009). Also wind turbines generate $20 \%$ more electricity at 100 meters altitude compared to 80 meters in the same area (Wind turbine models, 2019). In addition to this information more comprehensive research is needed to determine the technical wind potential areas. For this purpose it was tried to determine the wind speed and wind density of potential areas for the installation of wind turbines. Thus using the geographical information system and appropriate formulas the number of turbines and electricity generation that can be installed in potential areas has been calculated according to the diameter of the rotor (Table 1). Here wind speed, wind energy density and the duration of windy days are the main factors that determine the possible energy production capacity of wind potential areas. However there are also mechanical power losses in the gearbox, generator and converter during the operation of wind turbines. These are the main features that affect the capacity factor during power generation in the power station. As a result they cause the capacity factor of wind power plants to decrease up to $29 \%$ in energy production. Regardless of this even this rate is around $18-20 \%$ in wind power plants operating in Azerbaijan (The energy of Azerbaijan ..., 2019).

Table 1

Wind power generation depending on rotor diameter (Wind turbine models, 2019)

\begin{tabular}{|c|c|c|c|c|}
\hline $\begin{array}{c}\text { Rotor } \\
\text { diameter } \\
(\text { meter })\end{array}$ & $\begin{array}{c}\text { Turbine } \\
\text { coverage } \\
\text { area }\left(\mathrm{m}^{2}\right)\end{array}$ & $\begin{array}{c}\text { Wind } \\
\text { speed } \\
(\mathrm{m} / \mathrm{s})\end{array}$ & $\begin{array}{c}\text { The } \\
\text { density } \\
\text { of air } \\
\left(\mathrm{kg} / \mathrm{m}^{3}\right)\end{array}$ & $\begin{array}{c}\text { Energy pro- } \\
\text { duction mil- } \\
\text { lion KWh } \\
(\text { C.F. 29\% })\end{array}$ \\
\hline 30 & 706 & 4.5 & 1.10 & 10.5 \\
\hline 50 & 1963 & 5.5 & 1.16 & 56 \\
\hline 80 & 5026 & 7 & 1.21 & 309 \\
\hline
\end{tabular}

As a result of all these analyzes the most suitable total area for the installation of wind power plants was determined as $1143 \mathrm{~km}^{2}$ in Azerbaijan. The annual average wind speed of these defined areas varies between $3.5 \mathrm{~m} / \mathrm{s}$ and $7.5 \mathrm{~m} / \mathrm{s}$. In addition to the definition of potential areas it is necessary to select turbines with characteristics suitable for the wind regime of the selected regions to determine the wind energy production volume. For this purpose the technical characteristics of the most obvious wind turbines were analyzed compared to the wind regime of potential areas (Wind turbine models, 2019). As a result it was concluded that the installation of wind turbines with a rotor blade diameter of 20-30 meters in Nakhchivan, 3050 meters in Absheron and 50-100 meters in the Caspian Sea will be effective in terms of energy production efficiency (Table 2). For example, AWT-27 (diameter $27 \mathrm{~m}, 275 \mathrm{KW}$ ), Vestas V47700 (diameter $47 \mathrm{~m}, 700 \mathrm{KW}$ ) and Siemens SWT Offshore (diameter $93 \mathrm{~m}, 2.3 \mathrm{MW}$ ) wind turbines are the most proper turbines for installation (Wind turbine models, 2019). Based on the technical characteristics of the noted turbines the possible amount of electricity generation was calculated through the relevant formulas and software.

By dividing the measure of wind potential areas into the area covered by 1 wind turbine it is concluded that the number of turbines that can be installed was 5927 . This is equivalent to 4.2 billion $\mathrm{kWh}$ annual electricity generation volume of wind turbines with a capacity factor of $29 \%$. This calculated production volume corresponds to $17 \%$ of the country's current electricity demand. This ratio will occur as a result of the full use of the specified turbines based on the technical specifications of the wind turbines with three different sizes and power factors listed in Table 2. Additionally it is possible to determine the value of electricity produced compared to the amount of investment in wind turbines. Thus the cost of $1 \mathrm{~kW}$ wind turbines is $\$ 1500$ which will be equal to $\$ 75$ per year during 20 years of use (Murdock et al., 2019). The annual power generation capacity of the $1 \mathrm{~kW}$ turbine is around $2540 \mathrm{kWh}$ (C.F. 29\%). In this case the cost of electricity will be approximately $\$ 0.030(75 \$ / 2540 \mathrm{~kW})$. However only $69 \%$ of the investment for the installation of wind power plants belong to the turbines (Ragheb and Ragheb, 2011). In addition to the installation of wind turbines there are infrastructure, transformer, insurance, operation, annual maintenance and other costs. All this increases the production cost of $1 \mathrm{~kW}$ of wind energy by $21 \%$ to $\$ 0.037$, regardless of another unmeasurable spending. Despite this the wholesale price of $1.0 \mathrm{kWh}$ wind power for energy producers has set at 0.032 USD in Azerbaijan (Tariffs..., 2017). To this end measures to improve the use of wind energy must be stimulated. In addition Azerbaijan must fulfill the commitments set out in the Paris Climate Agreement in order to reduce carbon emissions and keep up with developed countries in the field of sustainable energy use (Paris agreement, 2015). However the intensive use of renewable energy resources in the country will lead to the development of different aspects of the green economy respectively. 
Wind energy potential areas by regions in Azerbaijan

\begin{tabular}{|c|c|c|c|c|c|c|}
\hline $\begin{array}{c}\text { Wind turbines } \\
(\text { e.g. })\end{array}$ & $\begin{array}{c}\text { Wind potential } \\
\text { regions }\end{array}$ & $\begin{array}{c}\text { General wind } \\
\text { potential } \\
\text { areas }\left(\mathrm{km}^{2}\right)\end{array}$ & $\begin{array}{c}\text { Technically } \\
\text { potential areas } \\
\left(\mathrm{km}^{2}\right)\end{array}$ & $\begin{array}{c}\text { Required area } \\
\text { for a turbine } \\
\left(\mathrm{m}^{2}\right)\end{array}$ & $\begin{array}{c}\text { Projected } \\
\text { number of } \\
\text { turbines }\end{array}$ & $\begin{array}{c}\text { Energy prod. } \\
\text { KWh } \\
(\mathrm{C} . \mathrm{F} .29 \%)\end{array}$ \\
\hline AWT-27 $(\mathrm{m})$ & Nakhchivan & 521 & 152 & 2381 & 1165 & 430 \\
\hline Vestas V47 $(\mathrm{m})$ & Absheron & 3900 & 883 & 1476 & 4181 & 2200 \\
\hline $\begin{array}{c}\text { Siemens SWT 2.3-93 } \\
(\mathrm{m})\end{array}$ & Caspian Sea & 1200 & 260 & 6793 & 526 & 1470 \\
\hline \multicolumn{2}{|c|}{ Total } & $\mathbf{1 2 9 5}$ & $\mathbf{5 6 7 7 6 3}$ & $\mathbf{1 0 ~ 8 3 0}$ & $\mathbf{5 9 2 7}$ & $\mathbf{4 2 0 0}$ \\
\hline
\end{tabular}

\section{Conclusions}

As can be seen many criteria play a role in determining the position of a wind farm. Using the multi-scale decision making a feature of the Geographic Information System, the data collected on each criterion were evaluated together. In line with this goal areas suitable for the construction of wind power plants have been identified in potential regions to be examined through GIS multi-scale decision-making studies. In addition to ArcGIS and SAM programs by analyzing wind meteorological indicators, related literature sources, and various maps it has been determined that high wind potential areas of Azerbaijan are $5621 \mathrm{~km}^{2}$.

As a result of the research it has been determined that after excluding unusable areas in terms of the installation principle of wind turbines 5621 $\mathrm{km}^{2}$ total areas are technically suitable for the construction of only $21 \%$ or $1143 \mathrm{~km}^{2}$ wind power

\section{REFERENCES}

Abdullayev Y.R., Karimzadeh O.O., Huseynov G.A., Mammadova G.V., Karimzadeh G.S. Improvement of verticalmagnetic levitation wind generator. Elm. Baku, Problems of Energy, No. 3, 2018, pp. 78-86 (in Azerbaijani).

Al-Yahyai S., Charabi Y., Gastli A., Al-Badi A. Wind farm land suitability indexing using multi-criteria analysis. Renewable Energy, V. 44, 2012, pp. 80-87, DOI.org/10.1016/ j.renene.2012.01.004.

Ayyubov A.C., Hajiyev G.A. Climate resources of the Azerbaijan SSR. Baku, 1984, 89 p. (in Azerbaijani).

Ayyubov A.C. Climate and human health of Baku and Absheron peninsula. Azerneshr. Baku, 1997, 124 p. (in Azerbaijani).

Beccali M., Cellura M., Ardente D. Decision making in energy planning: the ELECTRE multicriteria analysis approach compared to a fuzzy-sets methodology. Energy Conversion and Management, V. 39. No. 16-18. 1998, pp. 1869-1881, DOI.org/10.1016/S0196-8904 (98)00053-3.

Chaouachi A., Covrig C.F., Ardelean M. Multi-criteria selection of offshore wind farms: Case study for the Baltic States. Energy Policy, V. 103, 2017, pp. 179-192, DOI.org/ 10.1016/j.enpol.2017.01.018.

2014, 2015, 2016 Energy efficiency report. The State Agency for Alternative and Renewable Energy Sources of the Azerbaijan Republic (AREA). Baku, 2017, http://area.gov.az/ page/34 (in Azerbaijani). plants. These areas include the Absheron economicgeographical region, the Nakhchivan Autonomous Republic and the Caspian Sea coastal areas of the Khizi district.

It is possible to generate 4.2 billion $\mathrm{kWh}$ of electrical energy by making full use of the wind potential in the designated areas. This is equivalent to $17 \%$ of the country's energy demand. The cost of wind power generation was calculated as \$ 0.037 per $\mathrm{kWh}$. However an area of 30 hectares including almost all the infrastructure is needed to build a 100 MW wind farm. With this in mind it is possible to build a large number of power plants in the country with different wind turbines with a capacity of 100 MW. To this end a number of programs should be implemented to promote the widespread use of renewable energy sources to increase the number of wind turbines installed throughout the country and prevent environmental pollution.

\section{LITERATURE}

Abdullayev Y.R., Kərimzadə O.O., Hüseynov Q.Ә., Məmmədova G.V. Kərimzadə G.S. Şaquli oxlu maqnit levitasiyalı külək generatorunun təkmilləşdirilməsi. Elm. Bakı, Energetikanın problemləri, No. 3, 2018, s. 78-86.

Azərbaycan Respublikasında alternativ və bərpa olunan enerji və ondan səmərəli istifadə olunması sahəsində görülmüş işlər barədə Dövlət Agentliyinin 2014, 2015, 2016-ci illər Hesabat1. Azərbaycan Respublikası Alternativ və Bərpa Olunan Enerji Mənbələri üzrə Dövlət Agentliyi (AREA). Bakı, 2017, http://area.gov.az/page/34.

Azərbaycanın Energetikası. Statistik məcmuə. Azərbaycan Respublikasının Dövlət Statistika Komitəsi. Bakı, 2019,160 s.

Azərbaycan Respublikası: Milli Atlas. Azərbaycan Respublikası Dövlət Torpaq və Xəritəçəkmə Komitəsi. Bakı kartoqrafiya fabriki. Bak1, 2014, $444 \mathrm{~s}$.

Azərbaycanda ətraf mühit. Statistik məcmuə. Azərbaycan Respublikasının Dövlət Statistika Komitəsi. Bak1, 2019, 140 s.

Elektrik enerjisinin tarifləri. Elektrik enerjisinin ölkədaxili tarifləri. Azərbaycan Respublikasının Tarif (qiymət) Şurası. Bak1, 2017, http://www.tariffcouncil.gov.az/?/az/content/70/.

Energetika sahəsində 2017, 2018, 2019-cu illərdə görülmüş işlər barədə hesabatlar. Azərbaycan Respublikasının Energetika Nazirliyi, http://minenergy.gov.az/az/hesabatlar/illik-hesabatlar.

Әyyubov Ә.C., Haciyev Q.Ә. Azərbaycan SSR-nin iqlim ehtiyatları. Bak1, 1984, $89 \mathrm{~s}$. 
Environment in Azerbaijan. Statistical bulletin. The State Statistical Committee of the Azerbaijan Republic. Baku, 2019, 140 p. (in Azerbaijani).

Fagiano L. Control of tethered airfoils for high-altitude wind energy generation. PhD thesis. 2009, http://kitegen.com/ pdf/PhD_thesis_Fagiano_Final.pdf.

Georgopoulou E., Lalas D., Papagiannakis L. A multicriteria decision aid approach for energy planning problems: The case of renewable energy option. European journal of operational research, V. 103, No. 1, 1997, pp. 38-54, DOI.org/10.1016/S0377-2217 (96)00263-9.

Global Wind Atlas (GWA). Wind energy layers: Azerbaijan. 2019, https://globalwindatlas.info.

Huang J.P., Poh KL., Ang B.W. Decision analysis in energy and environmental modeling. Energy, V. 20, No. 9, 1995, pp. 843-855, DOI.org/10.1016/0360-5442 (95)00036-G.

Kapitsa A.P. Regional enviromental management. Publishing House of Moscow University. Moscow, 2003, 207 p.

Madatzadeh A.A. Natural-synoptic climate seasons in the Eastern Caucasus. Baku, 1973, 132 p. (in Russian).

Makhmudov R.N. Global climate change; causes and natural disasters. Hydrometeorology and environmental monitoring, Baku, No. 3, 2006, pp. 22-32 (in Azerbaijani).

Murdock H.E., Gibb D., André T., Appavou F., Brown A., Epp B., Sawin J.L. Renewables energy resources, Global Status Report, 2019, https://wedocs.unep.org/bitstream/handle/ 20.500.11822/28496/REN2019.pdf?sequence $=1$ \&isAllowe $\mathrm{d}=\mathrm{y}$

National atlas: Azerbaijan Republic. State Land and Cartography Committee of the Republic of Azerbaijan, Baku Cartography Factory. Baku, 2014, 444 p. (in Azerbaijani).

Observational materials of the Hydrometeorology Department of the Ministry of Ecology and Natural Resources of the Republic of Azerbaijan, 1990-2015. Hydrometeorology Bulletin. Baku, 67 p. (in Azerbaijani).

Paris agreement. United Nations Framework Convention on Climate Change. 2015, https://sustainabledevelopment.un.org/ content/documents/17853paris_agreement.pdf.

Porter H.O., Roberts D.C., Masson-Delmotte M.V., Zhai P.M. et al. IPCC, Special report on the ocean and cryosphere in a changing climate. IPCC: Summary for policymakers. 2019, 117 p., https://report.ipcc.ch/srocc/pdf/SROCC_FinalDraft _FullReport.pdf.

Quijano R., Botero S., Domínguez J. MODERGIS application: Integrated simulation platform to promote and develop renewable sustainable energy plans, Colombian case study. Renewable and Sustainable Energy Reviews, V. 16, 2012, pp. 5176-5187, DOI.org/10.1016/j.rser.2012.05.006.

Ragheb M., Ragheb A.M. Wind turbines theory - the Betz equation and optimal rotor tip speed ratio. Fundamental and advanced topics in wind power, V. 1, No.1, 2011, pp. 19-38.

Reports on the works in the field of energy in 2017, 2018, 2019. Ministry of Energy of the Azerbaijan Republic, http://minenergy.gov.az/az/hesabatlar/illik-hesabatlar (in Azerbaijani)

Shahbazov Sh.C., Yusubov I.M. Generating electrical energy by using wind energy at height from the ground. Elm. Baku, 2018, pp. $42-53$ (in Azerbaijani).

Shikhlinsky A.M. Heat balance atlas of the Azerbaijan SSR General Department of Geodesy and Cartography under the USSR Council of Ministers, Moscow, 1978, 92 p. (in Azerbaijani).

2015-2018 strategical plan. The State Agency for Alternative and Renewable Energy Sources of the Azerbaijan Republic (AREA). Baku, 2015, 32 p. (in Azerbaijani).

Electric energy tariffs. Tariffs. Domestic. Tariff (Price) Council of the Republic of Azerbaijan. Baku, 2017, http://www.tariffcouncil. gov.az/?/az/content/70/ (in Azerbaijani).
Әyyubov Ә.C. Bakı və Abşeron yarımadasının iqlimi və insan səhhəti. Azərnəşr. Bakı, 1997, 124 s.

Hidrometeoroloji bülleten. Azərbaycan Respublikası Ekologiya və Təbii Sərvətlər Nazirliyinin Hidrometeorologiya Departamentinin 1990-2015-ci illər müşahidə materialları. Bak1, $67 \mathrm{~s}$.

Mahmudov R.N. Qlobal iqlim dəyişmələri; səbəblər və təbii fəlakətlər. Hidrometrologiya və ətraf mühitin monitorinqi, No. 3, 2006, s. 22-32.

Strateji Plan (2015-2018). Azorbaycan Respublikası Alternativ və Bərpa Olunan Enerji Mənbələri üzrə Dövlət Agentliyi (AREA). Bak1, 2015, $32 \mathrm{~s}$.

Şahbazov Ş.C., Yusubov İ.M. Yer səthindən yüksəklikdə külək enerjisindən istifadə etməklə elektrik enerjisinin alınması. Elm. Bak1, 2018, s. 42-53.

Şıxlinski Ә.M. Azərbaycan SSR-nin istilik balans1 atlası. SSRİ Nazirlər Soveti Yanında Baş Geodeziya və Xəritəçilik İdarəsi. Moskva, 1978, $92 \mathrm{~s}$.

Yusifbəyli N.A., Nəsibov V.X., Đlizadə R.R. Elektrik enerjisinə olan ölkə daxili ehtiyacın proqnozlaşdırılması metodlarının qarşılıqlı müqayisəsi. Elm. Bakı, Energetikanın problemləri, No. 2, 2018, s. 56-64.

Al-Yahyai S., Charabi Y., Gastli A., Al-Badi A. Wind farm land suitability indexing using multi-criteria analysis. Renewable Energy, V. 44, 2012, pp. 80-87, DOI.org/10.1016/ j.renene.2012.01.004.

Beccali M., Cellura M., Ardente D. Decision making in energy planning: the ELECTRE multicriteria analysis approach compared to a fuzzy-sets methodology. Energy Conversion and Management, V. 39. No. 16-18. 1998, pp. 1869-1881, DOI.org/10.1016/S0196-8904 (98)00053-3.

Chaouachi A., Covrig C. F., Ardelean M. Multi-criteria selection of offshore wind farms: Case study for the Baltic States. Energy Policy, V. 103, 2017, pp. 179-192, DOI.org/ 10.1016/j.enpol.2017.01.018.

Fagiano L. Control of tethered airfoils for high-altitude wind energy generation. PhD thesis. 2009, http://kitegen.com/ pdf/PhD_thesis_Fagiano_Final.pdf.

Georgopoulou E., Lalas D., Papagiannakis L. A multicriteria decision aid approach for energy planning problems: The case of renewable energy option. European journal of operational research, V. 103, No. 1, 1997, pp. 38-54, DOI.org/ 10.1016/S0377-2217 (96)00263-9.

Global wind atlas (GWA). Wind energy layers: Azerbaijan. 2019, https://globalwindatlas.inf.

Huang J.P., Poh KL., Ang B.W. Decision analysis in energy and environmental modeling. Energy, V. 20, No. 9, 1995, pp. 843-855, DOI.org/10.1016/0360-5442 (95)00036-G.

Kapitsa A.P. Regional enviromental management. Publishing house of Mosow University. Moscow, 2003, 207 p.

Murdock H. E., Gibb D., André T., Appavou F., Brown A., Epp B., Sawin J.L. Renewables energy resources, Global Status Report 2019, https://wedocs.unep.org/bitstream/handle/20.500.11822/284 96/REN2019.pdf? sequence $=1 \&$ isAllowed=y

Paris agreement. United Nations Framework Convention on Climate Change, 2015, https://sustainabledevelopment.un.org/ content/documents/17853paris_agreement.pdf.

Porter H.O., Roberts D.C., Masson-Delmotte M.V., Zhai P.M. et al. IPCC, Special report on the ocean and cryosphere in a changing climate. IPCC: Summary for policymakers. 2019, 117 p., https://report.ipcc.ch/srocc/pdf/SROCC_FinalDraft _FullReport.pdf.

Quijano R., Botero S., Domínguez J. MODERGIS application: Integrated simulation platform to promote and develop renewable sustainable energy plans, Colombian case study. Renewable and Sustainable Energy Reviews, V. 16, 2012, pp. 5176-5187, DOI.org/10.1016/j.rser.2012.05. 
The energy of Azerbaijan. Statistical Bulletin. The State Statistical Committee of the Republic of Azerbaijan. Baku, 2019, 160 p. (in Azerbaijani).

The state of greenhouse gases in the atmosphere based on global observations through 2018. WMO greenhouse gas bulletin, No. 15, 2019, https://library.wmo.int/doc_num.php?explnum id $=10100$.

Wind turbine models (WTM), Wind turbines database. All manufactured. 2019, https://en.wind-turbine-models.com/turbines.

Yusifbayli N.A., Nasibov V.Kh, Alizadeh R.R. Comparative analysis of methods for forecasting domestic electricity needs. Elm. Baku, Problems of Energy, No. 2, 2018, pp. 56-64 (in Azerbaijani).
Ragheb M., Ragheb A.M. Wind turbines theory - the Betz equation and optimal rotor tip speed ratio. Fundamental and advanced topics in wind power, V. 1, No. 1, 2011, pp. 19-38.

The state of greenhouse gases in the atmosphere based on global observations through 2018. WMO greenhouse gas bulletin, No. 15, 2019, https://library.wmo.int/doc_num.php? explnum_id $=10100$.

Wind turbine models (WTM), Wind turbines database. All manufactured. 2019. https://en.wind-turbine-models.com/ turbines.

Мадатзаде А.А. Естественно-синоптические климатические сезоны Восточного Кавказа. Баку, 1973, 132 с.

\title{
ОПРЕДЕЛЕНИЕ ВЕТРОЭНЕРГЕТИЧЕСКИХ ПОТЕНЦИАЛЬНЫХ ОБЛАСТЕЙ В АЗЕРБАЙДЖАНЕ С ИСПОЛЬЗОВАНИЕМ МЕТОДА МНОГОКРИТЕРИАЛЬНОГО АНАЛИЗА РЕШЕНИЙ ГИС
}

\author{
Имамвердиев Н.С. \\ Институт Географии им. акад. Г.Алиева НАН Азербайджана \\ AZ1070, г.Баку, просп. Г.Джавида, 115: imamverdiyev.nicat@gmail.com
}

\begin{abstract}
Резюме. Целью статьи является выявление потенциальных ветроэнергетических полей Азербайджана с использованием метода пространственного многокритериального анализа на основе ГИС. Кроме того, с помощью этого метода можно предотвратить потери материала и времени путем расчета количества вырабатываемой электроэнергии. Точное определение областей, где будут установлены ветряные турбины, является важным критерием, влияющим на количество вырабатываемой энергии на электрических станциях. Так, исходя из принципов выбора местоположения ветряных турбин, были оценены такие важные условия, как инфраструктура, влияние турбин на прилегающие территории, близость к жилым районам, ветровой режим потенциальных регионов. Кроме того, были проанализированы такие факторы, как инвестиционные затраты, эксплуатационные расходы, коэффициент мощности и срок службы, которые определяют стоимость производства энергии в ветряных турбинах.

Технический ветроэнергетический потенциал республики оценивается примерно в 3000 МВт. Поскольку ветряные турбины невозможно установить во всех потенциальных зонах из-за воздействия на окружающую среду, на основе метода анализа многокритериальных решений ГИС был сделан вывод о том, что технически совместимые площади составляют 1143 км $^{2}$. В зависимости от скорости ветра и плотности мощности в этих обозначенных зонах возможное количество электроэнергии было рассчитано как 4.2 млрд.КВт-ч путем моделирования с использованием приложения System Advisor Model (SAM) с открытым исходным кодом. Этот объем эквивалентен 17\% текущего спроса на электроэнергию в стране. Кроме того, стоимость выработки электроэнергии ветряными электростанциями будет установлена в этих районах в среднем на уровне 0.037 долл. США за кВт-ч, что способствует широкому использованию ветряных турбин для предотвращения загрязнения окружающей среды.
\end{abstract}

Ключевые слова: возобновляемые источники энергии, энергия ветра, окружающая среда, потенциальные территории, стоимость электроэнергии

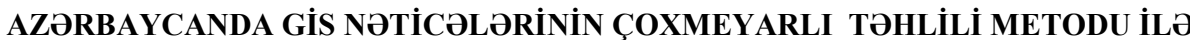

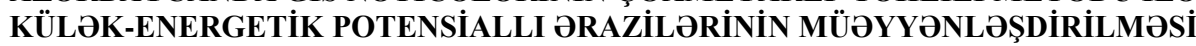

\author{
İmamverdiyev N.S. \\ AMEA H.Ә. Dliyev adına Coğrafiya İnstitutu, \\ AZ1070, Bakı ş., H. Cavid prosp., 115: imamverdiyev.nicat@gmail.com
}

\begin{abstract}
Xülasə. Məqalə GIS əsaslı məkansal çoxmeyarlı analiz metodundan istifadə edərək Azərbaycanın potensial külək-energetik sahələrini müəyyənləşdirmək məqsədi daşıyır. Bundan əlavə, bu üsulla elektrik enerjisinin istehsal həcmini hesablamaqla maddi və vaxt itkisinin qarşısını almaq mümkündür. Külək turbinlərinin quraşdırılacağı yerlərin dəqiq müəyyənləşdirilməsi elektrik stansiyalarının enerji istehsalına təsir edən vacib bir meyardır. Beləliklə, külək turbinlərinin yer seçiminin prinsiplərinə əsaslanaraq, infrastruktur, turbinlərin ətraf ərazilərə təsiri, yaşayış sahələrinə yaxınlığı və potensial bölgələrin külək rejimi kimi vacib şərtləri qiymətləndirilmişdir. Bundan əlavə, külək turbinlərində enerji istehsalının maya dəyərini təyin edən investisiya xərcləri, əməliyyat xərcləri, güc amili və xidmət müddəti kimi amillər də təhlil edilmişdir.

Respublikanın texniki külək-energetik potensialı $3000 \mathrm{MVt}$ civarında qiymətləndirilmişdir. Külək turbinlərinin ətraf mühitə təsiri səbəbindən bütün potensial ərazilərdə quraşdırılması mümkün olmadığından, texniki cəhətdən uyğun sahələrin GIS nəticələrinin çoxmeyarlı təhlili metodu əsasında $1143 \mathrm{~km}^{2}$ olduğu aşkar edilmişdir. Müəyyən olunan ərazilərin külək sürətindən və güc sıxlığından asılı olaraq, açıq mənbəli System Advisor Model (SAM) tətbiqi ilə modelləşdirmə yolu ilə mümkün elektrik enerjisinin istehsal miqdarı 4.2 milyard kVt/saat olaraq hesablanmışdır. Bu həcm ölkənin elektrik enerjisinə olan tələbatının 17\%-nə bərabərdir. Bundan əlavə, bu ərazilərdə külək elektrik stansiyalarında elektrik enerjisinin istehsal dəyəri orta hesabla bir kVt/saat üçün 0.037 dollar təşkil edəcəkdir ki, bu da ətraf mühitin çirklənməsinin qarşısını almaq üçün külək turbinlərinin geniş istifadəsini təmin edir.

Açar sözlar: barpa olunan enerji mənbalari, külak enerjisi, atraf mühit, potensial sahalar, elektrik enerjisinin dayari
\end{abstract}

